\title{
The Interpretation of "in Context" Verbal Probability Expressions Used in International Financial Reporting Standards - Evidence from Poland
}

\section{Jerzy Gierusz - Katarzyna Kolesnik - Sylwia Silska Gembka*}

\begin{abstract}
:
The objective of this paper is to specify in which way Polish accounting professionals manage to interpret "in context" verbal probability expressions (VPEs) from IFRS. Taking into account the Polish accounting professionals attachment to the prudence principle and the Polish mindset, we research here whether they have a conservative approach when interpreting those expressions. For the purpose of our study we distributed a questionnaire and asked a sample of accountants and auditors from Poland to interpret the term "probable" used in IFRS to establish the threshold for recognition of various accounting elements. Our findings provide evidence that the differences in interpretation of "in context" VPEs by Polish accounting professionals exist. We also find that the level of conservatism shared by Polish accountants and auditors affects their individual accounting judgment.
\end{abstract}

Key words: Financial reporting; IFRS; Interpretation; Professional judgment; Verbal probability expressions.

JEL classification: M41.

\section{Introduction}

It is generally accepted that comparability of financial reports may be best achieved through compliance with IFRS (Armstrong et al., 2010). However, the application of uniform accounting standards alone does not automatically unify the solutions adopted by various countries. This is because interpretation of the rules

Jerzy Gierusz; University of Gdansk, Faculty of Management, Department of Accounting, ul. Armii Krajowej 101, 81-824 Sopot, Poland, <rachunkowosc.wzr@ug.edu.pl>.

Katarzyna Kolesnik; University of Gdansk, Faculty of Management, Department of Accounting, ul. Armii Krajowej 101, 81-824 Sopot, Poland, <katarzyna.kolesnik@ug.edu.pl>.

Sylwia Silska Gembka; University of Gdansk, Faculty of Management, Department of Accounting, ul. Armii Krajowej 101, 81-824 Sopot, Poland, <sylwia.silska-gembka@ug.edu.pl>. The article is processed as an output of a research project registered by the National Science Centre, under the registration number DEC-2012/07/B/HS4/03012. 
Gierusz, J. - Kolesnik, K. - Silska Gembka, S.: The Interpretation of "in Context" Verbal Probability Expressions Used in IFRS - Evidence from Poland.

or principles contained in the IFRS may be different across nations, which in turn threatens comparability (Doupnik and Richter, 2004).

Lack of consistency in the field of interpretation is particularly obvious when using verbal probability expressions (VPEs) (i.e. probable, reasonable assurance, virtually certain, remote, no longer probable). These expressions commonly occur in IFRS and require the exercise of judgment in accounting for transactions and events. For example IAS 37 par. 14 requires a recognition of provision when "it is probable" that an outflow of resources embodying economic benefits will be required to settle the obligation. However IFRS do not provide sufficient structure to frame that judgment. This is because IFRS are largely principle-based standards that emphasise broad principles and the substance of transactions (Bierstaker, Kopp and Lombardi, 2016).

Previous research shows that these expressions may have low communication efficiency, as there are significant differences in their interpretations (Simon, 2002). As it is, the lack of consistency in the VPEs interpretation results in the lack of consistency in specific standards interpretation and application in which they occur (Amer, Hackenbrack and Nelson, 1994), which in turn limits the usefulness of the financial statement made on their basis (Simon, 2002).

Poland, like the majority of EU countries, started applying IFRS on a large scale on 1 January $2005^{1}$. The IFRS adoption meant for Poland implementation of the Anglo-Saxon model of accounting, replacing the continental model of accounting. Hence, Polish accountants and auditors are facing the necessity to apply regulations which not only diminish the continental model of prudence principle, but leave the path open to individual judgment as well, not being given explicit guidelines as to the manner of application in return. Thus Polish accountants have had to adapt to accepting changes that introduced more general principles and less prescriptive detail. Given the fact that in Poland, IFRS "meets the Slav culture, that is greatly reluctant to risk taking, and fixing their sentiments on the past" (Kabalski, 2012, p. 25), the implementation of IFRS meant for Poland "an intellectual, mental and cultural earthquake" (Kabalski, 2012, p. 17). It was regarded in Poland as an unprecedented event, which would cause many difficulties.

Having the above context in mind, the objective of this paper is to specify in which way Polish accounting professionals manage to interpret "in context" verbal probability expressions assorted from IFRS. Taking into account their attachment

\footnotetext{
1 All Polish listed companies and banks are required to prepare consolidated financial statements
} according to IFRS. The use of IFRS is not compulsory for non - listed companies. 
to the prudence principle and the Polish mindset, we research here whether they have a conservative approach when interpreting those expressions.

Our findings provide evidence that the differences in interpretation of "in context" VPEs exist. The results also indicate that the level of conservatism shared by Polish accountants and auditors may affect their individual accounting judgment.

This paper contributes to prior research of professional accountants' judgments under IFRS by delivering the first results for Poland. While a number of studies related to differences in interpretation of IFRS have been undertaken mainly in the US, Australia and New Zealand, there are only a few studies in the European context, and no such research has previously been undertaken in Poland. The Polish case study may be of interest because Poland is one of the largest countries in Central Eastern Europe (CEE) and widely understood as being one of the most successful "transition countries" in Europe (Lesko, 2007). Moreover, accounting principles in Poland, just like in other Eastern European countries, not only had to be reformed for a market economy, but also aligned with the IFRS which made the transition more complex than in other emerging markets (Kosmala-MacLullich and Gurau, 2004).

This paper starts with a review of prior research, followed by research questions, methodology, results, discussion, and conclusion.

\section{Review of Prior Research}

Much of the research on verbal probability expressions in the domain of accountancy relates to the interpretation of uncertainty expressions used in Financial Accounting Standards (SFAS) No. 5 Accounting for Contingencies, published by FASB (Amer, Hackenbrack and Nelson, 1995; Du and Stevens, 2011). Other studies refer to the various national accounting standards (Chesley, 1986; Amer, Hackenbrack and Nelson, 1994; Simon, 2002). The interpretation of VPEs used in IFRS has also been discussed in several studies (Doupnik and Richter, 2003, 2004; Doupnik and Riccio, 2006; Teixeira and Silva, 2009; Salleh et al., 2011a, 2011b; Chand, Cummings and Patel, 2012; Tang and Yang, 2016; Huerta, Petrides and Braun, 2016).

In the European context, the research in this area is still quite recent and there are few reference studies (Simon, 2002; Doupnik and Richter, 2003, 2004; Teixeira and Silva, 2009).

Researchers use various methods to assess the interpretation of VPEs. Some studies require respondents to provide a single numerical estimate that best represents the probability associated with each VPE (e.g. Amer, Hackenbrack and Nelson 1994, 1995; Simon, 2002; Doupnik and Richter, 2003; Salleh et al., 2011b; 
Gierusz, J. - Kolesnik, K. - Silska Gembka, S.: The Interpretation of "in Context" Verbal Probability Expressions Used in IFRS - Evidence from Poland.

Chand, Cummings and Patel, 2012). Other studies require respondents to establish the threshold for recognition of various accounting elements (e.g. Amer, Hackenbrack and Nelson, 1994, 1995; Simon, 2002; Doupnik and Richter, 2004; Teixeira and Silva, 2009).

The studies also differentiate between those that investigate the interpretation of VPEs "in context", (1) that is contextualised in standards, through excerpts of accounting standards (e.g. Doupnik and Richter, 2004; Doupnik and Riccio, 2006; Salleh et al., 2011b, Chand, Cummings and Patel, 2012) or (2) refers to real situations which respondents are likely to encounter in their working environment (e.g. Amer, Hackenbrack and Nelson 1994, 1995; Du and Stevens, 2011) as compared with studies which ask for the interpretation of these expressions "in isolation", that is, without contextual scenarios (e.g. Simon, 2002; Doupnik and Richter, 2003; Teixeira and Silva, 2009).

The results obtained by Doupnik and Richter (2004) suggest that VPEs are interpreted differently when placed "in context", in contrast to their previous research (Doupnik and Richter, 2003) where these expressions were not contextualised in standards, where the findings were not the same. Moreover evidence provided by $\mathrm{Du}$ and Stevens (2011) indicates that verbal-to-numeric translation of VPEs is unstable and context dependent. Similar findings were formulated by two psychologists Windschitl and Wells (1996). The authors suggest that VPEs are consistent with intuitive thinking rather than with rule-based reasoning implicit in the use of numerical probabilities. Consistent with their arguments, they found verbal expressions to be more influenced by context than numerical expressions. Beyth-Marom (1982) also noted that judgments are more variable when an expression appears in context than when it is judged out of context. Considering the above, in this work we analyse "in context" VPEs asking respondents to assign the threshold for recognition of various accounting elements.

Most of the studies report inconsistent interpretation of VPEs between or within respondents' groups. For example Amer, Hackenbrack and Nelson (1994) indicated varying levels of agreement between auditors. Similarly Chesley's (1986) results showed considerable ambiguity in the interpretation of VPEs. As Chesley (1986, p. 196) states “common words such as 'probable' or 'likely' will cause wide variations in interpretation and should not be used for specific communication of uncertainty in general situations sensitive to inaccurate interpretations".

Researchers who have conducted cross-national studies (Doupnik and Richter, 2003, 2004; Doupnik and Riccio, 2006; Chand, Cummings and Patel, 2012) noticed that culture is likely to be a significant factor affecting these 
interpretations, while other do not support this hypothesis (Salleh et al., 2011b). According to Huerta, Petrides and Braun (2016), the manner in which the VPEs are interpreted depends also on the language the phrase is expressed in. Doupnik and Richter (2003), by contrast, proved that there are differences in the interpretation of those same terms by German and English speaking accountants. This difference might result from an influence of the language culture effect, or alternatively - difficulties in translation due to non-existing language equivalents in German. Thus, the translation of standard terms from English into languages of the countries where those regulations are used is vital from the point of view of their later interpretation (Silska Gembka, 2016). The difficulty in the IFRS translation originates from using the wording referring to probability and uncertainty. Huerta, Petrides and Braun (2013) maintain that, owing to their ambiguity, these types of expressions cause more problems in the translation between expressions and wording, the meaning and jargon of which is unique to accountancy.

These inconsistencies in interpretations of VPEs, as Laswad and Mak (2000) argue, could lead to obstacles in the application of accounting standards and also to various perceptions of accounting disclosure.

\section{Research Questions}

As mentioned the Polish IFRS adoption meant the implementation of principle based accounting replacing rule based accounting. As noted by Nelson (2003, p. 91), "rules include specific criteria, 'bright line' thresholds, examples, scope restrictions, exceptions, subsequent precedents, implementation guidance, etc.". In contrast, "principles-based" standards refer to fundamental understandings that dominate any other rule established in the standard (Salvador and Trombetta, 2008). Thus Polish professional accountants had to learn to adopt changes that introduced more general principles and less prescriptive detail.

The Polish legal system is based on Roman law when "specific rules take precedence over general rules" (Kosmala-MacLullich, 2003, p. 468) unlike Common law when "general clauses such as true and fair view may override specific rules" (Kosmala-MacLullich, 2003, p. 468). As Jaruga (1993) states, Polish tradition has more in common with the codified approach to accounting regulations than with common law. Moreover Poland, like other countries in the CEE region, has experienced a framework of accounting drawn from the system under a communist regime where the law making process did not involve consultation with society. As a consequence, very prescriptive provisions were imposed. 
Gierusz, J. - Kolesnik, K. - Silska Gembka, S.: The Interpretation of "in Context" Verbal Probability Expressions Used in IFRS - Evidence from Poland.

For the first time since 1945, the Polish legal solutions had in terms of accountancy come closer to the European systems in 1991 with the announcement of the Order by Minister of Finance on the accountancy principles (Kolaczyk 1997, p. 35). This is regarded as a breakthrough in the accountancy development in Poland. The economic entities were made to run the accountancy in the way giving a reliable and true reflection of their financial standing. For the first time, the principles of the Polish accountancy were based on the true and fair view concept (Sulowska, 2003, p. 726). Moreover Polish accounting professionals were obliged to recognise provisions in the amounts able to cover potential economic risk (Kabalski, 2012, p. 16-17). Thus for the first time they had to assess the probability of that risk.

The Accounting Act passed by the Polish Parliament on 29 September 1994 was a real milestone in the development of Polish accountancy which introduced the regulations allowing for the description of the entities in terms of commerce. However, elements of the British tradition in the Polish system, including the role of judgment in the realisation of true and fair view (TFV), were hardly traceable.

Although, after this period, the Polish accounting law was expanded by many solutions convergent with the IFRS2, which indicates an inclination towards the Anglo-Saxon tradition, the truth is that accounting practice in Poland is still reflected in normative, rule-based compliance. Polish accountants and auditors still think along the rule-based lines and also still expect solid patterns. Kabalski (2012, p. 21) states that "it is incomprehensible for many Poles that there are accountancy principles not containing accounting schemes". The ingrained habit of Polish accountants to be given detailed instructions resulted mainly from the necessity to obey very rigorous tax principles, and detailed charts of accounts etc. (Kabalski, 2012).

Before implementing IFRS, accountants in Poland had no need to make a subjective judgment referring to VPEs as they were rare in Polish accounting regulations. Having the above in mind, the research question addressed in this study is:

RQ1: Do Polish accounting professionals manage to interpret VPEs occurring in IFRS consistently?

There is an agreement in the literature that accounting conservatism exists (Ball, Robin and Sadka, 2008). The philosophy of conservatism relates to the preference of anticipating no profits and providing for all probable losses. Thus conservatism tends to the preference of a cautious approach to recognition, so accountants who

2 For example, IFRS were expected to be a key benchmark for the Polish Accounting Standards Committee when preparing Polish National Accounting Standards (KRS). 
are conservative report the lowest value among possible alternative values for gains and assets but the highest alternative values for losses and liabilities (Chanchani and Willett, 2004). Further, the level of conservatism shared by the accountants might affect their interpretations of VPEs as they are used to establish the threshold for the recognition of various accounting elements (gains, assets, losses, liabilities) (Doupnik and Richter, 2004).

Gray (1988) gives evidence of the conservatism existing in countries applying the continental accounting model, which was represented, among others, by Poland (Winiarska, 2009). Having had the prudence principle as the basis of the Polish accountancy regulations, the diminishment of this principle by the implementation of IFRS was a major change for Polish accounting professionals. Although the amendments of the Accounting Act put a strong emphasis on the notion of fair value and departure from the historic cost, decreasing the importance of prudence in the realisation of the "true and fair view" (Kosmala-MacLullich, 2003, p. 483), the continental model of accounting is still very strong in Poland (Kabalski, 2012). Studies show that Polish accountants "deem prudence the most important principle of evaluation in accountancy and consider it a realistic image of the company rather than pessimistic.” (Honko, 2008, p. 265)

A profound distrust and widely spread pessimism towards the world found in Poles (Skarzynska, 2005) stimulates a powerful avoidance of uncertainty to be identified with Polish society (G. Hofstede and G.J. Hofstede, 2007). But as a result, a high level of uncertainty avoidance might indicate a high level of conservatism from the accounting point of view (Gray, 1988; Radebaugh and Gray, 2002). What is more, the features of a "homo sovieticus" personality emerges heavily from the Polish society (Wnuk-Lipinski, 2008), which amongst other facets, is characterised by inability to solve problems, subjection of one's own actions and decisions to instructions from other people or institutions and which is characteristic of a conservative attitude -fear of risk. Kabalski et al. (2012) noticed that in Poland the "homo sovieticus" style of personality occurs quite often (although it does not dominate) among people who work in accountancy.

Taking into account the fact that VPEs are used to establish the threshold for recognition of asset and items that increase income and the recognition of liabilities and also items that decrease income, we posit that accountants from more conservative cultural environments would require a higher degree of certainty for recognising profit than loss. Thus, based on the above discussion the second research question chosen for this study is:

RQ2: Do Polish accounting professionals prefer a conservative approach to the interpretation of "in context" VPEs used in IFRS? 
Gierusz, J. - Kolesnik, K. - Silska Gembka, S.: The Interpretation of "in Context" Verbal Probability Expressions Used in IFRS - Evidence from Poland.

\section{Methodology}

The methodology adopted in this empirical study follows the general literature and Doupnik and Richter (2004) and Doupnik and Riccio (2006), in particular. For the purpose of our study we distributed a questionnaire and asked a sample of Polish accounting professionals to interpret the "probable" expression used in IFRS to establish the threshold for recognition of various accounting elements.

The questionnaire was composed of a collection of eight fragments selected from the IFRS which contained the expression "probable". The survey included excerpts of the IFRS published by the Accountant Association in Poland - being official translation of the International Financial Reporting Standards of the International Accounting Standards Board. Data characterising the respondents (gender, position held, years of work experience, experience in the multinational company, the ACCA qualifications, statutory auditor qualifications, frequency of the IFRS application at work) was included as well.

The study was confined to the use of the expression "probable", as it is the most frequently used probability term in IFRS. It is also used in a variety of contexts (Doupnik and Richter, 2004). Some authors note that possible interpretations of the expression "probable" are influenced by contextual feature, whereas interpretations of "remote" and "reasonably estimable" are not (Amer, Hackenbrack and Nelson, 1995).

This term is used to establish the threshold for recognition of items resulting in:

- financial result increase (e.g. IAS 18 para 22 required recognition of revenue when it was probable that the economic benefit associated with the transaction would flow to the enterprise),

- financial result decrease (e.g. according to IAS 11 para 36 when it was probable that total constructions contract costs would exceed total contract revenue, the expected loss was to be recognised as an expense immediately) ${ }^{3}$.

The respondents' tasks were to determine the numerical probability, which - in their opinion - would determine the threshold resulting in the recognition of revenue (IAS 11 para 23, IAS 18 para 22), losses (IAS 11 para 36), provisions (IAS 37 para 14), assets (IAS 12 para 24, IAS 16 para 7, IAS 38 para 57) and the assets' impairment (IAS 36 para 12). After reading each paragraph respondents were asked: "In this context, probable corresponds to a probability greater than what percentage?" Much of the accounting research used the scale of zero percent to 100 percent in establishing the thresholds to each VPEs (for example Doupnik

3 IAS 18 and IAS 11 were replaced by IFRS 15 however the term "is probable" is still used. 
and Richter, 2004; Doupnik and Riccio, 2006; Chand, Cummings and Patel, 2012). We follow a similar approach in our study.

The quoted IAS excerpts have been divided into two groups, depending on the context the VPEs have been used in:

- group 1: Resulting in measurement of items increasing the financial result (IAS 11 para 23; IAS 12 para 24; IAS 16 para 7; IAS 18 para 22; IAS 38 para 57),

- group 2: Resulting in measurement of items decreasing the financial result (IAS 11 para 36; IAS 36 para 12; IAS 37 para 14).

As the "probable" expression is used for the measurement ${ }^{4}$ of the position making up the two indicated groups, the level of the respondents' conservatism should influence the interpretation of the analysed category. If Polish respondents assign a higher numerical probability that determines the threshold for increases in income than the threshold for decreases in income, this means that conservatism affects the interpretation of this expression.

The point estimates of probability expressions were summarised using mean, standard deviation and coefficient of variation. The Wilcoxon signed rank test was also applied, in order to find out whether the probability extent for the events in resulting in financial result increase, as evaluated by the accountants and auditors, differs substantially from the probability extent for the events resulting in its decrease.

The surveyed group consisted of accounting professionals (financial directors, chief accountants, auditors and other accountancy department employees). The involvement of financial directors and chief accountants was not coincidental as they are responsible for the preparation of financial statements, which calls for a professional judgment when evaluating the probability of the occurrence of a given event. Due to their positions, they are required to have knowledge concerning the IFRS application in practice (Simon, 2002). Similarly, auditors use their professional judgment to evaluate probability in the course of audits of financial statements. Also, the auditors - specifically in small joint stock companies which have not used the IFRS before - are required to offer subject matter support during the financial statement preparation (Hogendoorn, 2006).

All respondents were recruited during their compulsory training courses organised by the Polish Chamber of Auditors (PIBR) and the Accountant Association in

4 The descriptive measures were also used for surveys carried out by Amer, Hackenbrack and Nelson (1994), Simon (2002), Doupnik and Richter (2003, 2004), Salleh et al. (2011b). 
Gierusz, J. - Kolesnik, K. - Silska Gembka, S.: The Interpretation of "in Context" Verbal Probability Expressions Used in IFRS - Evidence from Poland.

Poland $(\mathrm{SKwP})^{5}$. The printed questionnaires were sent to randomly selected training centres. A total of 984 questionnaires were sent out. A total of 351 questionnaires were returned, $332^{6}$ of which were usable as the basis for the analysis of the results. The survey did not include the forms where the respondents did not include demographic information, or made formal mistakes. The survey was carried out at the end of 2013, into 2014. Table 1 shows the characteristics of the study sample.

\section{Tab. 1 Population and sample}

\begin{tabular}{|c|c|c|}
\hline Subject & $\begin{array}{c}\text { Number of } \\
\text { persons }\end{array}$ & Missing data \\
\hline Study sample Total, including: & 332 & 2 \\
\hline - Women & 236 & \\
\hline - Men & 94 & \\
\hline Position held: & & 14 \\
\hline - Auditor & 183 & \\
\hline - Financial Director, Chief Accountant & 60 & \\
\hline - Other & 75 & \\
\hline Statutory Auditor qualifications & 264 & 22 \\
\hline ACCA qualifications & 37 & 23 \\
\hline Professional experience in multinational company & 80 & 9 \\
\hline IFRS application at work & & 12 \\
\hline - Regularly & 61 & \\
\hline - Occasionally & 190 & \\
\hline - Never & 69 & \\
\hline
\end{tabular}

Source: Authorial computation.

Women were in the majority among the tested sample, which is not surprising. As Kabalski and Szwajcar (2015) indicate, in Poland most accountants are female. The subjects were between 21 and 85, the average age was 53. The respondents had been working as auditors or accountants for 25.43 years on average, not less than two years and a maximum of 66 years. 183 persons were employed as auditors and 264 were qualified as auditors. 37 respondents had ACCA qualifications. 80 persons were working for multinational companies with an

${ }^{5}$ In order to examine financial statements in Poland, the accountants must seek qualifications for auditors issued by the Polish Chamber of Auditors (PIBR). In order to provide auditing services the public, qualified individuals must be members of the PIBR and included on its register of auditors that it must maintain. They also must participate in compulsory training courses even if they are not currently in audit practice. Otherwise they will be excluded from the PIBR register.

6 We had a response rate of $33.74 \%$. 
average period of employment of 8.63 years. Over half of the number occasionally applied IFRS in their work. All respondents were Polish, born in Poland.

U Mann Whitney, Kruskal Wallis and Spearmann correlation tests ${ }^{7}$ were employed to identify demographic variables (including the gender, position held, years of work experience, experience in multinational companies, ACCA qualifications, statutory auditor qualifications, and frequency of the application of IFRS at work) which might affect the numeric interpretation of the "probable" expression. Our study does not find evidence that Polish interpretations of VPEs are affected by these demographic variables. Gender was not a differentiating factor of the manner the "probable" expression was interpreted and included in each of the analysed standards. The obtained results are statistically insignificant. Next factors analysed in the survey was the age of the interviewed persons and the time span of their occupational experience in accountancy or auditing. In the cases of almost all analysed IASs, the use of which results in decrease or increase in the financial result, the relation between the probability assessment and the number of years of experience was statistically insignificant. IAS 16, par. 7 is an exception, where the analysis showed that with both age and experience period, the level of probability rose when assessing the future economic benefits related to the assets component, which allowed for its presentation in the statement on the financial position ( $\mathrm{p}$-value $=.002$ for age and $\mathrm{p}$-value $=.036$ for occupational experience). No other factors, i.e. position held, experience in multinational companies, ACCA qualifications, statutory auditor qualifications, or frequency of the IFRS application at work, lead to statistically different results in the probability assessment in all addressed areas.

\section{Results}

Results will be presented under two headings corresponding to the research questions addressed in this study.

\section{Do Polish accounting professionals manage to interpret VPEs occurring in IFRS consistently?}

Firstly, the Polish translation of the English expression "is probable" used in IFRS is covered by a number of phrases: "istnieje prawdopodobienstwo", "jest prawdopodobne", "prawdopodobne jest" which convey the same sense as the one used in the original term. However, in IAS 36 par. 12, the original English phrase "are expected" has also been translated into Polish as "jest prawdopodobne" (the English equivalent "is probable") (Silska Gembka, 2016).

\footnotetext{
7 The distribution of the obtained results was not in line with the normal distribution.
} 
Gierusz, J. - Kolesnik, K. - Silska Gembka, S.: The Interpretation of "in Context" Verbal Probability Expressions Used in IFRS - Evidence from Poland.

The average extent of probability (Table 2) for the items resulting in the increase of financial result amounted to $63.50 \%$ while for the item resulting in the decrease, the average probability was $56.23 \%$. The obtained differences are statistically significant $(\mathrm{z}=7.87 ; \mathrm{p}$-value $<.001)$. The results indicate average variability in the case of the majority of expressions from the first group and a large variability in the case of the second group.

Tab. 2 Interpretation of the "probable" expression in selected IASs

\begin{tabular}{|c|c|c|c|c|c|}
\hline \multirow[b]{2}{*}{ IAS/Para } & \multirow[b]{2}{*}{$\begin{array}{c}\text { Original } \\
\text { English } \\
\text { expressions }\end{array}$} & \multirow[b]{2}{*}{$\begin{array}{c}\text { Polish } \\
\text { translation }\end{array}$} & \multicolumn{3}{|c|}{$\mathrm{N}=\mathbf{3 1 8} / \mathbf{3 3 2}$} \\
\hline & & & Mean & $\begin{array}{c}\text { Std. } \\
\text { Deviation } \\
\text { (SD) } \\
\end{array}$ & $\begin{array}{c}\text { Coefficient } \\
\text { of Variation } \\
(\mathrm{CV})\end{array}$ \\
\hline \multicolumn{6}{|c|}{ Group 1: Measurement of items increasing the financial result } \\
\hline $11 / 23$ & is probable & $\begin{array}{c}\text { istnieje } \\
\text { prawdopodobienstwo }\end{array}$ & $\begin{array}{c}61.22 \\
(\mathrm{~N}=327)\end{array}$ & 21.76 & 35.54 \\
\hline $12 / 24$ & is probable & $\begin{array}{c}\text { jest } \\
\text { prawdopodobne }\end{array}$ & $\begin{array}{c}63.81 \\
(\mathrm{~N}=332)\end{array}$ & 23.80 & 37.30 \\
\hline $16 / 7$ & is probable & $\begin{array}{c}\text { istnieje } \\
\text { prawdopodobienstwo }\end{array}$ & $\begin{array}{c}67.82 \\
(\mathrm{~N}=327)\end{array}$ & 23.61 & 34.81 \\
\hline $18 / 22$ & is probable & $\begin{array}{c}\text { jest } \\
\text { prawdopodobne }\end{array}$ & $\begin{array}{c}64.43 \\
(\mathrm{~N}=323)\end{array}$ & 25.79 & 40.03 \\
\hline $38 / 57$ & probable & prawdopodobne & $\begin{array}{c}64.68 \\
(\mathrm{~N}=318) \\
\end{array}$ & 23.91 & 36.97 \\
\hline \multicolumn{2}{|c|}{ Mean average } & & 63,50 & 17.40 & 27.41 \\
\hline \multicolumn{6}{|c|}{ Group 2: Measurement of items decreasing the financial result } \\
\hline $11 / 36$ & is probable & $\begin{array}{c}\text { istnieje } \\
\text { prawdopodobienstwo }\end{array}$ & $\begin{array}{c}56.54 \\
(\mathrm{~N}=330)\end{array}$ & 25.21 & 44.59 \\
\hline $36 / 12$ & is expected & $\begin{array}{c}\text { prawdopodobne } \\
\text { jest }\end{array}$ & $\begin{array}{c}55.25 \\
(\mathrm{~N}=321)\end{array}$ & 23.64 & 42.79 \\
\hline $37 / 14$ & is probable & $\begin{array}{c}\text { prawdopodobna } \\
\text { jest }\end{array}$ & $\begin{array}{c}56.27 \\
(\mathrm{~N}=319) \\
\end{array}$ & 24.07 & 42.78 \\
\hline \multicolumn{2}{|c|}{ Mean average } & & 56.23 & 18.67 & 33.20 \\
\hline
\end{tabular}

Source: Authorial computation.

In the case of each analysed standard it was usually associated with a probability threshold greater than 50\% (Table 3). Such answers were true for 25-32\% indications in the case of expressions, the application of which results in an increase in the financial result and 36-39\% in the case of expressions where the application of which results in a decrease. The next probability threshold most frequently given by the respondents was over $80 \%$. 
Tab. 3 Interpretation of the "probable" expression in selected IAS

\begin{tabular}{|c|c|c|c|c|c|c|c|c|c|c|c|}
\hline \multirow[b]{2}{*}{ IAS/Para } & \multicolumn{11}{|c|}{ In this context "probable" corresponds to a probability greater than what } \\
\hline & -10) & $\begin{array}{l}<10- \\
20)\end{array}$ & $\begin{array}{l}<20- \\
30)\end{array}$ & $\begin{array}{c}<30- \\
40)\end{array}$ & $\begin{array}{l}<40- \\
50)\end{array}$ & $\begin{array}{c}<50- \\
60)\end{array}$ & $\begin{array}{c}<60- \\
70)\end{array}$ & $\begin{array}{l}<70- \\
80)\end{array}$ & $\begin{array}{c}<80- \\
90)\end{array}$ & $\begin{array}{l}<90- \\
100)\end{array}$ & $\begin{array}{c}= \\
100\end{array}$ \\
\hline \multicolumn{12}{|c|}{ Group 1: Measurement of items increasing the financial result (\%) } \\
\hline $11 / 23$ & 3.67 & 1.53 & 1.22 & 2.14 & 4.28 & 30.87 & 12.84 & 11.64 & 19.88 & 10.09 & 1.84 \\
\hline $12 / 24$ & 3.01 & 1.51 & 2 & 2.11 & 1.20 & 31.93 & $0.0 J$ & 12.35 & 18.67 & 25 & 6.33 \\
\hline $16 / 7$ & 3.36 & 1.22 & 0.9 & 1.83 & 1.83 & 26.3 & 6.42 & 11.93 & 18.65 & 19.57 & 7.95 \\
\hline $18 / 22$ & 0 & 1.55 & 1.24 & 2.79 & 1. & 2 & 5 & 13 & 21 & 15.79 & 5.26 \\
\hline $38 / 57$ & 77 & 1.89 & 2.52 & 1.89 & 2.20 & 25.79 & 7.23 & 14.46 & 19.18 & 17.61 & 3.46 \\
\hline \multicolumn{12}{|c|}{ Group 2: Measurement of items decreasing the financial result (\%) } \\
\hline $11 / 36$ & 5.15 & 2.73 & 4.85 & 3.33 & 3.33 & 38.79 & 6.97 & 8.48 & 11.82 & 8.79 & 5.76 \\
\hline $36 / 12$ & 4.67 & 2.49 & 4.36 & 4.67 & 6.23 & 36.14 & 8.72 & 9.03 & 14.02 & 6.23 & 3.44 \\
\hline $37 / 14$ & 5.02 & 2.82 & 3.13 & 5.64 & 2.20 & 36.99 & 10.35 & 9.09 & 12.85 & 8.15 & 3.76 \\
\hline
\end{tabular}

Source: Authorial computation.

It referred to nearly $19 \%$ to close to $22 \%$ of answers concerning standards from the first group and nearly $12 \%$ to $14 \%$ in the case of standards from the second group. The remaining $49 \%-55 \%$ responses were distributed over the remaining thresholds.

The distribution of results listed in Table 2 and 3 show the differences in the interpretation of the analysed expression among the surveyed group. This suggests that in Poland VPEs occurring in IFRS are interpreted inconsistently.

\section{Do Polish accounting professionals prefer a conservative approach to the interpretation of "in context" VPEs used in IFRS?}

The second research question examines whether Polish accountancy professionals assign a higher numerical probability that determines the threshold for increases in income than the threshold for decreases in income. To answer this question a comparison of mean levels of probability for the "probable" expression was made, determined for each of the selected IAS excerpts, the use of which results in an increase in the financial result with a mean level of probability for each of the IAS excerpts, whose use results in its decrease. Table 4 presents the results. 
Gierusz, J. - Kolesnik, K. - Silska Gembka, S.: The Interpretation of “in Context" Verbal Probability Expressions Used in IFRS - Evidence from Poland.

Tab. 4 Comparison of mean level of probability for the "probable" expression in selected IAS excerpts resulting in increase and decrease in financial result

\begin{tabular}{|c|c|c|c|c|}
\hline \multicolumn{3}{|c|}{ Comparison of mean probability for IAS } & \multirow[b]{2}{*}{$\mathrm{z}$} & \multirow[b]{2}{*}{ p-value } \\
\hline $\begin{array}{l}\text { Measurement } \\
\text { of items increasing } \\
\text { the financial result }\end{array}$ & & $\begin{array}{c}\text { Measurement } \\
\text { of items decreasing the } \\
\text { financial result }\end{array}$ & & \\
\hline $11 / 23$ & \multirow{5}{*}{$>$} & \multirow{5}{*}{$11 / 36$} & -3.64 & 0.00 \\
\hline $12 / 24$ & & & -4.26 & 0.00 \\
\hline $16 / 7$ & & & -6.98 & 0.00 \\
\hline $18 / 22$ & & & -5.14 & 0.00 \\
\hline $38 / 57$ & & & -5.22 & 0.00 \\
\hline $11 / 23$ & \multirow{5}{*}{$>$} & \multirow{5}{*}{$36 / 12$} & -4.12 & 0.00 \\
\hline $12 / 24$ & & & -4.80 & 0.00 \\
\hline $16 / 7$ & & & -7.26 & 0.00 \\
\hline $18 / 22$ & & & -6.55 & 0.00 \\
\hline $38 / 57$ & & & -6.56 & 0.00 \\
\hline $11 / 23$ & \multirow{5}{*}{$>$} & \multirow{5}{*}{$37 / 14$} & -3.53 & 0.00 \\
\hline $12 / 24$ & & & -4.98 & 0.00 \\
\hline $16 / 7$ & & & -6.68 & 0.00 \\
\hline $18 / 22$ & & & -5.04 & 0.00 \\
\hline $38 / 57$ & & & -5.58 & 0.00 \\
\hline
\end{tabular}

Source: Authorial computation.

Polish accountants and auditors require a higher level of probability to be able to recognise items resulting in an increase in the financial result than to recognise items resulting in its decrease. Significant differences occur in all analysed cases. This points to the opinion that the respondents are more likely to recognise loss than profit. Thereby, the interpretation of the term "probable" is affected by inclination to conservatism.

\section{Discussion}

The results of our research indicate that the adoption of IFRS allows for considerable freedom in interpreting the analysed expressions, which may result in limited effective comparability of financial statements, if based on such liberal regulations.

This issue is vital. The decisions concerning probability threshold assigned to particular VPEs might have an influence on financial statements. An accountant who indicates a lower probability threshold will increase the number of transactions or events compared to the accountant, for whom that probability threshold is higher. Thus, if for an accountant a lower threshold of probability is 
associated with such an expression which refers to an operation which makes the financial result increase, such an accountant will recognise sooner the transactions resulting in the increase. Thus the financial results of such an entity might be higher even with identical initial data for two entities. However, if it refers to the operations the recognition of which makes the financial result decrease, it means that such an accountant will show more transactions that cause loss, i.e. the entity's financial results might be lower (Silska-Gembka, 2016).

Our study is comparable to those conducted by Doupnik and Richter (2004), Doupnik and Riccio (2006), and Salleh et al. (2011b). Table 5 reports the results for comparison of the mean numerical probabilities for the 'probable' expression used in our study with those studies.

It appears that for all analysed cases, the probabilities indicated by Polish accountants are lower than those indicated by other groups in other studies. Thus, it increases the instances of a transaction or event recognised in a Polish financial statement, because they will be recognised earlier than in compared countries. As far as the context of decreasing financial result is concerned, Polish accountants seem to have a more cautious approach to the interpretation of the "probable" expression when compared to professionals from other countries, as they have assigned the lowest percentage.

Tab. 5 Comparison of mean level of probability for the "probable" expression in our study with other studies

\begin{tabular}{|c|c|c|c|c|c|c|c|}
\hline \multirow[t]{2}{*}{ IAS/Para } & \multirow{2}{*}{$\begin{array}{c}\begin{array}{c}\text { Our } \\
\text { study }\end{array} \\
\text { Poland }\end{array}$} & \multicolumn{2}{|c|}{$\begin{array}{c}\text { Doupnik } \\
\text { and Richter } \\
(2004)\end{array}$} & \multicolumn{2}{|c|}{$\begin{array}{c}\text { Doupnik } \\
\text { and Riccio } \\
(2006)\end{array}$} & \multicolumn{2}{|c|}{$\begin{array}{l}\text { Salleh et al. } \\
\text { (2011b) }\end{array}$} \\
\hline & & German & US & Brazil & US & Chinese & English \\
\hline \multicolumn{8}{|c|}{ Group 1: Measurement of items increasing the financial result } \\
\hline $11 / 23$ & 61.22 & 74.47 & 74.27 & 77.65 & 74.94 & 69.17 & 68.16 \\
\hline $16 / 7$ & 67.82 & 71.44 & 73.35 & - & - & 69.58 & 69.74 \\
\hline $18 / 22$ & 64.43 & 76.35 & 69.33 & 78.43 & 73.58 & - & - \\
\hline \multicolumn{8}{|c|}{ Group 2: Measurement of items decreasing the financial result } \\
\hline $11 / 36$ & 56.54 & 65.56 & 74.12 & 73.19 & 71.56 & 72.71 & 71.05 \\
\hline
\end{tabular}

Source: Authorial computation.

We note the fact that in an increasing financial result context, the percentage probabilities assigned by Polish accountants are the lowest as well. This phenomenon might result from the fact - as Zemojtel-Piotrowska (2009) puts it that in some spheres of life, Poles tend to show an unrealistic optimism in that they expect an increase in their income in the future although their hope is later not reflected in reality. Thus, taking into account the results obtained by us, they are 
Gierusz, J. - Kolesnik, K. - Silska Gembka, S.: The Interpretation of "in Context" Verbal Probability Expressions Used in IFRS - Evidence from Poland.

satisfied with a lower level of their occurrence probability to show their revenue than those from other countries listed in the Table 5.

Hogendoorn (2006) emphasises the fact that we cannot expect a total or nearly total comparability. The opportunity of many subjective choices results in the "diversity impeded to achieve this goal" (Durocher and Gendron, 2011, p. 242). Limiting this diversity would only be possible if firm rules have been provided, or the International Financial Reporting Interpretations Committee (IFRIC) have issued a number of detailed interpretations. Yet, such a solution is contrary to the approach adopted by the IFRS based on principles (Beerbaum, Piechocki and Weber, 2017). However, as Hogendoorn (2006) notes, even in such a situation, reaching a complete comparability is impossible due to the subjective decisions the judgments are influenced by.

\section{Conclusion}

A number of studies provide evidence that professional accountants and auditors do not interpret VPEs contained in the accounting standards in the same way. The results of our study also show that in Poland differences exist in the interpretation of "in context" VPEs. Moreover, we find that the level of conservatism shared by Polish accounting professionals affect their individual accounting judgment as they assign a higher numerical probability to establish the threshold for recognition of items resulting in increasing the financial results than for recognition of items resulting in decreasing the financial results.

To assess the probability of occurrence of an event expressed by means of VPEs, a subjective judgment is demanded at two stages. First, accounting professionals must be able to assess whether "is probable" means probability for example over $50 \%$ or perhaps over $60 \%$. Next, they must decide if that threshold has been achieved in that case. Our study refers to the first stage. Our findings suggest that differences in the interpretation of probability terms may lead to inconsistencies in the application of the recognition criteria in which those terms are used. It is thus worth carrying out a survey concerning the second stage. It would help the conviction that the interpretation of the VPEs is responsible for the lack of unity in standards application.

This study is the first examination of the VPEs in a Polish context. Prior research has focused mainly on the US, Australia, New Zealand, United Kingdom, Germany, Portugal and China. Future research could extend over other European Union countries coping with transition economies, to determine whether the results are similar. What is more, the Polish case shows that the continental accountancy model, with its conservative approach to valuation, is still present in the Polish accountants' minds, and influences the interpretation of the VPEs. 
Comparing other countries, Doupnik and Richter (2004) also argue that the high level of conservatism of German accountants influences their subjective judgment. Furthermore, their findings suggest that conservatism does not affect the interpretation of VPEs when referring to US accountants. It might thus occur that conservatism affects the interpretation by accountants coming from other countries who use the continental model of accountancy. It would be worthwhile to carry out further study on this subject, mainly because its result might make a substantial contribution to accountancy studies. Part of this research should include the development of skills necessary to carry out such estimates.

This paper focuses only on the analysis of one probability expression: the "probable". This expression was assessed only in two contexts: those resulting in measurement of items increasing the financial result and those resulting in measurement of items decreasing the financial result. Future research can focus on other uncertainty expressions used in IFRS, for example: "reasonable probability", "reasonable assurance", "remote" or "no longer probable".

\section{References}

Amer, T., Hackenbrack, K., Nelson, M., 1994. Between-auditor differences in the interpretation of probabilities phrases. Auditing: A Journal of Practice and Theory 13, 126-136. Available from:<search.proquest.com/openview/d4628a23daf0e3 aea10daf4d4712635b/1?pq-origsite $=$ gscholar\&cbl=31718>. [07 January 2013].

Amer, T., Hackenbrack, K., Nelson, M., 1995. Context-dependence of auditors' interpretations of the SFAS No. 5 probability expressions. Contemporary Accounting Research 12, 25-39. DOI: 10.1111/j.1911-3846.1995.tb00479.x.

Armstrong, Ch. S., Barth, M.E., Jagolinzer, A.D., Riedl, E.J., 2010. Market reaction to the adoption of IFRS in Europe. The Accounting Review 85, 31-61. DOI: 10.2308/accr.2010.85.1.31.

Ball, R., Robin A., Sadka, G., 2008. Is financial reporting shaped by equity markets or by debt markets? An international study of timeliness and conservatism. Review of Accounting Studies 13, 168-205. DOI: 10.1007/s11142007-9064-x.

Beerbaum, D., Piechocki, M., Weber, Ch., 2017. Is there a Conflict between Principles-based Standard Setting and Structured Electronic Reporting with XBRL? European Financial and Accounting Journal 3, 33-52. DOI: 10.18267/j.efaj. 186 . 
Gierusz, J. - Kolesnik, K. - Silska Gembka, S.: The Interpretation of "in Context" Verbal Probability Expressions Used in IFRS - Evidence from Poland.

Beyth-Marom, R., 1982. How probable is probable? A numerical translation of verbal probability expressions. Journal of Forecasting 1, 257-269. DOI: 10.1002/for.3980010305.

Bierstaker, J.L., Kopp, L.S., Lombardi, D.R., 2016. Are financial professionals ready for IFRS? An exploratory study. Advances in Accounting 35, 1-7. DOI: 10.1016/j.adiac.2016.04.004.

Chanchani, S., Willett, R., 2004. An empirical assessment of Gray's accounting value constructs. The International Journal of Accounting 39, 125-154. DOI: 10.1016/j.intacc.2004.02.003.

Chand, P., Cummings, L., Patel, C.H., 2012. The effect of accounting education an national culture on accounting judgments: a comparative study of Anglo-Celtic and Chinese culture. European Accounting Review 21, 153-182. DOI: 10.1080/09638180.2011.591524.

Chesley, G.R., 1986. Interpretation of uncertainty expressions. Contemporary Accounting Research 2, 179-199. DOI: 10.1111/j.1911-3846.1986.tb00613.x.

Doupnik, T., Riccio, E., 2006. The influence of conservatism and secrecy on the nterpretation of verbal probability expressions in the Anglo and Latin cultural areas. The International Journal of Accounting 41, 237-261. DOI: 10.1016/j.intacc.2006.07.005.

Doupnik, T., Richter, M., 2004. The impact of culture on the interpretation of "in context" verbal probability expressions. Journal of International Accounting Research 3, 1-20. DOI: 10.2308/jiar.2004.3.1.1.

Doupnik, T., Richter, M., 2003. Interpretation of uncertain expressions: a crossnational study. Accounting, Organizations and Society 28, 15-35. DOI: 10.1016/S0361-3682(02)00010-7.

Du, N., Stevens, K., 2011. Numeric-to-verbal translation of probability expressions in SFAS 5. Managerial Auditing Journal 26, 248-262. DOI: 10.1108/02686901111113190.

Durocher, S., Gendron, Y., 2011. IFRS: on the docility of sophisticated users in preserving the ideal of comparability. The European Accounting Review 20, 233262. DOI: $10.1080 / 09638181003687869$.

Gray, S.J., 1988. Towards a Theory of Cultural Influence on the Development of Accounting Systems Internationally. Abacus 24, 1-15. DOI: 10.1111/j.14676281.1988.tb00200.x.

Hofstede, G., Hofstede, G.J., 2007. Kultury i organizacje. Zaprogramowanie umyslu (2nd ed.). PWE, Warszawa. 
Honko, S., 2008. Koncepcja ostroznej wyceny w rachunkowosci, Wydawnictwo Naukowe Uniwersytetu Szczecinskiego, Szczecin.

Hoogendoorn, M., 2006. International accounting regulation and IFRS implementation in Europe and beyond - experiences with first-time adoption in Europe. European Accounting Review 3, 23-26. DOI: 10.1080/09638180600920087.

Huerta, E., Petrides, Y., Braun, G.P., 2016. Interpretation of probability expressions in accounting: The effects of frame switching. Journal of International Accounting, Auditing and Taxation 27, 1-12. DOI: 10.1016/j.intaccaudtax.2016.06.001.

Huerta, E., Petrides, Y., Braun, G.P., 2013. Translation of IFRS: language as a barrier to comparability. Research in Accounting Regulation 25, 1-12. DOI: 10.1016/j.racreg.2012.11.007.

Jaruga, A., 1993. Changing rules of accounting in Poland. European Accounting Review 1, 115-126. DOI: 10.1080/09638189300000010.

Kabalski, P., 2012. Wybrane problemy stosowania Miedzynarodowych Standardow Sprawozdawczosci Finansowej w Polsce. Organizacja, kultura, osobowosc, jezyk. Wydawnictwo Uniwersytetu Lodzkiego, Lodz.

Kabalski, P., Szwajcar, J., 2015. Feminizacja studiow w zakresie rachunkowosci w Polsce - przyczyny i skutki. Zeszyty Teoretyczne Rachunkowosci 137, 85-106.

Kolaczyk, Z., 1997. Rachunkowosc finansowa. Wydawnictwo Akademii Ekonomicznej, Poznan.

Kosmala-Maclullich, K., 2003. The true and fair view construct in the context of the Polish transition economy: some local insights. European Accounting Review 12, 465-487. DOI: 10.1080/0963818031000087844.

Kosmala-Maclullich, K., Gurau, K.C., 2004. The relationship between economic performance and accounting system reform in the CEE region: The cases of Poland and Romania. Available from: <2.hw.ac.uk/sml/downloads/cert/wpa/2004/dp0406.pdf.>. [31 October 2017].

Larson, R.K., Street, D.L., 2004. Convergence with IFRS in an expanding Europe: progress and obstacles identified by large accounting firms. Journal of International Accounting, Auditing and Taxation 13, 89-119. DOI: 10.1016/j.intaccaudtax.2004.09.002.

Laswad, F., Mak, Y.T., 2000. Interpretations of probability expressions: a comparison between standards - setters and accountants. Pacific Accounting Review 11, 241-254. DOI: 10.1108/eb037945. 
Gierusz, J. - Kolesnik, K. - Silska Gembka, S.: The Interpretation of "in Context" Verbal Probability Expressions Used in IFRS - Evidence from Poland.

Lesko, D., 2007. Polish financial reporting principles in transition. Baltic Journal of Management 2, 55-66. DOI: 10.1108/17465260710720246.

Mucha, J., 1994. Metody geostatystyczne w dokumentowaniu zloz. Wydaw. AGH., Krakow.

Nelson, M.W., 2003. Behavioral evidence on the effects of principles- and rulesbased standards (commentary). Accounting Horizons 17, 91-104. DOI: 10.2308/acch.2003.17.1.91.

Radebaugh, L. H., Gray, S.J., 2002. International accounting and multinational enterprises (5th ed.). John Wiley, USA.

Salleh, S.I.M., Gardner, J. C., Sulong, Z., Carl, B., McGowan, C. B., 2011a. A comparison of the interpretation of "in context" verbal probability expressions used in international accounting standards by the demographic factors of students studying at United Kingdom universities. Available from: <intellectbase.org/e_publications/proceedings/IHART_Summer_2011.pdf\#page=7 1>. [31 October 2017].

Salleh, S.I.M., Gardner, J. C., Sulong, Z., Carl, B., McGowan, C. B., 2011b. The interpretation of in context verbal probability expressions used in international accounting standards: a comparison of English and Chinese students studying at English speaking universities. Journal of International Education Research 7, 6779. DOI: $10.19030 /$ jier.v7i2.4251.

Salvador, C., Trombetta, M., 2008. On the global acceptance of IAS/IFRS accounting standards. The logic and implications of the principles-based system, Journal of Accounting and Public Policy 27, 455-461. DOI: 10.1016/j.jaccpubpol.2008.09.003.

Silska Gembka, S., 2016. Kultura, jezyk, tlumaczenie. Wybrane problemy interpretacji Miedzynarodowych Standardow Sprawozdawczosci Finansowej. Zarzadzanie i Finanse 4, 285-301.

Simon, J., 2002. Interpretation of probability expressions by financial directors and auditors of UK companies. The European Accounting Review 11, 601-629. DOI: $10.1080 / 09638180220125599$.

Skarzynska, K., 2005. Czy jestesmy prorozwojowi? Wartosci i przekonania ludzi a dobrobyt i demokratyzacja kraju, in: Drogosz, M. (ed.), Jak Polacy przegrywaja. Jak Polacy wygrywają. GWP, Gdansk, 69-92.

Sułowska, J., 2003. Ewolucja systemu rachunkowosci polskiej w okresie transformacji systemowej, in: Sojak S. (ed.), Historia, wspolczesnosc i 
perspektywy rachunkowosci w Polsce. Uniwersytet Mikolaja Kopernika, Torun, p.725-740.

Tang, F., Yang, L., 2016. The interpretation differences of verbal probability expressions in principles-based accounting standards: Evidence from China. International Journal of Accounting Auditing and Performance Evaluation 12, 287-312. DOI: 10.1504/IJAAPE.2016.077893.

Teixeira, C., Silva, A.F., 2009. The interpretation of verbal probability expressions used in the IAS/IFRS: Some Portuguese evidence. Revista de Estudos Politecnicos Polytehnical Studies Review 7, 057-073.

Windschitl, P.D., Wells, G.L., 1996. Measuring psychological uncertainty: Verbal versus numeric methods. Journal of Experimental Psychology: Applied 2, 343364. DOI: 10.1037/1076-898X.2.4.343.

Winiarska, K., 2009. Rachunkowosc miedzynarodowa. ODDK, Gdansk.

Wnuk-Lipinski, E., 2008. Dlugie pozegnanie. Homo sovieticus dzisiaj. Tygodnik Powszechny 2., Available fom: <tygodnikpowszechny.pl/dlugie-pozegnanie133302>. [31 October 2017].

Zemojtel-Piotrowska, M., 2009. Narzekanie i roszczeniowosc a postrzeganie swiata spolecznego. Wyd. Uniwersytetu Gdanskiego, Gdansk. 
